these countries used directive planning in the difficult period of their development, subsequently moving from it to indicative planning, which is proposed to be repeated in the current Russian realities.

Keywords: strategic planning, national security, France, China (PRC), directive planning, indicative planning

САИДОВ Санжар Шавкатович - доктор политических наук (PhD), Узбекский государственный университет мировых языков (100138, Узбекистан, г. Ташкент, ул. Кичик Халка Йули, 21a; s.saidov. uz@gmail.com

\title{
ПЯТЬ ПРОБЕЛОВ В ГОСУДАРСТВЕННОЙ КАДРОВОЙ ПОЛИТИКЕ УЗБЕКИСТАНА
}

Аннотация. В данной научной статье анализируются особенности и проблемы государственной кадровой политики в Республике Узбекистан. Отмечаются пять пробелов в сфере подбора, перестановки и подготовки государственных служащих в Узбекистане.

Ключевые слова: государственная кадровая политика, административная реформа, “утечка мозгов", креативный класс

$\mathrm{B}$ современных общественно-политических условиях в узбекистанском обществе государственная кадровая политика становится все более важным фактором эффективного госуправления. Ее роль постоянно возрастает вместе с ростом влияния человеческого фактора на решение политических, социальных, экономических и других проблем. Для того чтобы государственная кадровая политика стала действенной и результативной, необходима ее оптимизация как социально-политического института.

После резких политических событий в Узбекистане осенью 2016 г. наряду с социальными, экономическими и политическими изменениями в общественной жизни произошли некоторые модификации в кадровой политике государства. В одном из первых выступлений президента Ш. Мирзиеева отмечалось, что кадровая политика государства находится в «катастрофическом» положении и нуждается в кардинальных реформах. Исходя из этого мы попытались проанализировать некоторые особенности и пробелы кадровой политики в Узбекистане.

1. Слабая нормативно-правовая база. В 2017 г. была принята Концепция административной реформы в Республике Узбекистан и дорожная карта по ее реализации. В концепции отмечается, что главная цель этих документов - создание системы государственного управления, отвечающей общемировым тенденциям нового развития и способной обеспечить полноценную реализацию намеченных реформ, регулировать отношения в области государственной службы, своевременно выявлять и эффективно решать проблемы общественно-политического и социально-экономического развития страны ${ }^{1}$.

Однако эти документы не создали единую систему подбора кадров в органах государственного и хозяйственного управления. В выборе и перестановке

${ }^{1}$ Концепция административной реформы в Республике Узбекистан. 08.09.2017. Доступ: http://lex.uz/acts/3331176 (проверено 25.07.2020). 
кадров все еще используются старые методы и технологии. До сих пор в стране не был принят закон о государственной службе.

Актуальным вопросом остается планирование и оценка деятельности госслужащих центральных и местных государственных органов. В настоящее время не существует конкретный критерий, позволяющий объективно оценивать деятельность кадров, работающих в определенном государственном органе и ведомстве.

Сегодня в Узбекистане как никогда ранее ощущается острая необходимость создания соответствующей нормативно-правовой и институциональной базы государственной службы. Еще одной приоритетной задачей является внедрение современных методов управления и развития человеческих ресурсов, а также выведение на качественно новый уровень системы подготовки, переподготовки и повышения квалификации управленческих кадров.

2. Личностный фактор. За последние 3 года по инициативе президента Узбекистана произошли серьезные кадровые изменения. Эти кадровые реформы коснулись администрации президента, кабинета министров, службы безопасности и региональных исполнительных властей. Хотя эти изменения могут показаться, с одной стороны, позитивными, они фактически привели к переводу старых действующих чиновников с одной должности на другую. Также существует тенденция возвращения к власти ряда лиц, которые служили в предыдущей системе.

Отсутствие социальных лифтов в стране приводит к преобладанию личностных взглядов в кадровой политике. В этом случае профессионализм, компетентность, научный и практический опыт человека, назначаемого на государственную должность, не учитывается, а наоборот, на первый план выходит лояльность этого человека к руководителю.

Также актуальным вопросом является внедрение «карьерной модели» государственной службы, предусматривающей последовательное прохождение должностных ступеней служебной карьеры с регулярным повышением квалификации кадров, а также с категорированием государственных гражданских служащих и присвоением им квалификационных рангов (чинов).

3. Командно-административное управление. В соответствии с постановлением президента Узбекистана от 8 августа 2017 г. «О первоочередных мерах по обеспечению ускоренного социально-экономического развития регионов» все области (районы и города) республики по комплексному социально-экономическому развитию разделены на 4 сектора. Сектора возглавят 4 руководителя: хакимы (главы администраций) областей, районов и городов, руководители органов прокуратуры, внутренних дел и государственной налоговой службы.

Эта ситуация охватывает все сферы государственного и общественного управления в регионах, каждая из которых также занимается деятельностью, выходящей за рамки их функций. Например, прокурор района (начальник 2-го сектора) должен также курировать многие другие направления - банковское дело, финансы, инвестиции, образование, культуру, благоустройство района и другие направления в своем секторе. Это, в свою очередь, приводит к использованию административно-командных методов в управлении на местах.

Обеспечить социально-экономическое развитие можно только путем полной реализации механизмов управления открытого рыночного типа и экономической свободы. В этом процессе необходимо внедрить функции политического маркетинга и политического менеджмента в отношениях с государственными органами.

4. «Утечка мозгов». Коррупция на различных уровнях государственного и общественного управления, а также многие недостатки и пробелы в кадровой 
политике приводят к так называемой утечке мозгов из страны. Благодаря фонду «Умид» в первые годы независимости многие молодые люди получили образование в развитых странах Европы, США и Азии. Они были кадрами нового поколения - с новыми идеями и навыками. Однако изменения в государственной политике в 2000 г. и тенденция борьбы с «западными вредными идеями» привели к недоверию к этим кадрам в руководстве страны. В конце концов, многим из них пришлось уехать за границу.

Кроме этого, каждый год по различном учебным программам США, ЕС, Японии, Южной Кореи талантливая молодежь уезжает за границу, и многие из них остаются там на постоянной основе. На сегодняшний день выходцы из Узбекистана успешно работают в известных компаниях, включая банковские, финансовые, научные и общественные организации развитых стран мира.

Во время своего визита в Соединенные Штаты в 2017 г. и в Германию в 2019 г. президент Ш. Мирзиеев встретился с узбекистанцами, живущими и работающими в этих странах. Он пригласил их в Узбекистан и обещал свою поддержку. Однако многие наши соотечественники, добившиеся успеха за рубежом, не спешат возвращаться в Узбекистан.

5. Надо изменить философию. Реформа государственной кадровой политики должна начинаться с изменения ее общей философии. Полная прозрачность и справедливость должны быть обеспечены в системах подбора, перестановки, подготовки, переподготовки и повышения квалификации государственных служащих.

Сегодня развитие социально-экономических и общественно-политических процессов в мире, в свою очередь, является основой прогресса в странах и связано с образованием класса руководителей нового типа. Ярким примером этого можно назвать креативный класс [Florida 2002], формирование которого стало новым трендом в последнее время. В современных обществах идеи характеризуются как экономический товар. Новые идеи и новые инициативы в первую очередь производятся креативным классом. У всех богатств страны (полезные ископаемые, производственные мощности и другие ресурсы) есть конец, только новые, инновационные идеи можно считать бесконечным и неограниченным ресурсом.

В условиях модернизации общества формируется новая парадигма государственной кадровой политики как социального института общества, демократически ориентированного в своем развитии. Кадровая политика из средства борьбы за власть или ее удержание все больше превращается в важнейшее условие общественного развития, в основной ресурс социального управления, который требует анализа и теоретического осмысления [Пицик 2006: 7]. В этом контексте формирование в Узбекистане нового класса руководителей и государственных служащих с новой философией становится стратегической задачей на новом этапе развития.

\section{Список литературы}

Florida R. 2002. Bohemia and Economic Geography. - Journal of Economic Geography. Vol. 2. Is. 1. P. 55-71.

Пицик Н.И. 2006. Государственная кадровая политика в органах власти и управления как социальный институт. М.: Изд-во ИСПИ РАН. 48 с. 
SAIDOV Sanjar Shavkatovich, Dr.Sci. (Pol.Sci.) (PhD), Uzbekistan State World Language University (21a Kichik

Halka Yuli St, Tashkent, Uzbekistan, 100138; s.saidov.uz@gmail.com)

\section{FIVE GAPS IN THE STATE PERSONNEL POLICY OF UZBEKISTAN}

Abstract. The article analyzes the features and problems of the state personnel policy in the Republic of Uzbekistan. The author notes five gaps in the selection, rearrangement and training of civil servants in Uzbekistan.

Keywords: state personnel policy, administrative reform, brain drain, creative class

УДК 94 (517.30)

ГОМБОЖАПОВ Александр Дмитриевич - кандидат исторических наук, ведущий научный сотрудник отдела истории и культуры Центральной Азии Института монголоведения, буддологии и тибетологии СО РАН (670042, Россия, Республика Бурятия, г. Улан-Удэ, ул. Сахьяновой, 6; agoтbоzh@ gmail.com)

\section{К ВОПРОСУ О ПОЛИТИЧЕСКОМ УСТРОЙСТВЕ МОНГОЛИИ XVI в.}

Аннотация. В статье рассматривается проблема государственности в кочевом обществе. Автор пишет о маятниковом характере динамики политических процессов у кочевников, методология которого активно разрабатывается в последнее время, что служит отражением нелинейности социополитической эволюции. Автор полагает, что в период XVI - начала XVII в. в монгольском обществе происходит ряд уникальных преобразований, свидетельствующих о становлении устойчивой тенденции к государственности.

Ключевые слова: кочевники, власть, племя, буддизм, Монголия, Алтан-хан

$\mathrm{B}$ кочевниковедении проблема политогенеза и характера властных отношений в номадных обществах остается одной из фундаментальных [Крадин 1992]. За последнее время произошло накопление большого объема разнородных данных, полученных в разных областях знаний, - от археологии до антропологии народов этнографического времени, которые значительно дополнили представление о развитии кочевых обществ. В то же время стало очевидным, что многие факты стали вступать в противоречие с устоявшимися взглядами на характер социальной и политической эволюции кочевников. Исследования археологических культур кочевников Евразии показывают, что уже на раннем этапе имеются свидетельства о высоко иерархизированных обществах, глубоко зашедших процессах расслоения в них, появлении неравенства и сложной системы общественных статусов. Открываются новые и изучаются известные поселенческие памятники (городища), материалы которых фиксируют долговременное существование сложных хозяйственных и торговых комплексов, что говорит об особой роли городищ в обществе кочевников. Хотя они и уступают по масштабам и своему числу, а генезис их носит скорее скачкообразный характер, все же можно говорить об определенных внутренних тенденциях разделения труда и урбанизации в кочевой среде. На сегодняшний момент общепри- 